\title{
cAMP-Dependent Protein Kinase and Protein Phosphorylation in Developing Rat Lung
}

\author{
JEFFREY A. WHITSETT, ${ }^{(39)}$ SUSAN MATZ, AND CHARLOTTE DAROVEC-BECKERMAN \\ Department of Pediatrics, Newborn Division, University of Cincinnati Medical Center, Cincinnati, Ohio, USA
}

Summary

Protein kinase activity that is dependent on $3^{\prime}, 5^{\prime}$-Cyclic adenosine monophosphate (cAMP-PK), $\left[{ }^{3} \mathrm{H}\right] \mathrm{cAMP}$ binding, and cAMP-dependent protein phosphorylation were identified and partially characterized in cytosolic preparations of rat lung from day 18 of gestation to adulthood. Major cAMP-dependent phosphoproteins in lung preparations were compared to those in cytosol from purified Type II epithelial cells. Both Type I and Type II regulatory subunits of CAMP-PK were identified in fetal and adult lung. Inhibition of specific $\left[{ }^{3} \mathrm{H}\right] \mathrm{cAMP}$ binding to lung cytosol (to the regulatory subunit of the CAMP-dependent protein kinase) followed the order of potency: cAMP > cGMP; adenosine, ADP, and ATP were inactive. Scatchard plots of saturation experiments with $\left[{ }^{3} \mathrm{H}\right] \mathrm{cAMP}$ and lung cytosol were linear. Dissociation constant $\left(K_{D}\right)$ for cAMP binding was approximately 2$3 \mathrm{nM}$, and did not change significantly with age. In contrast, binding capacity varied significantly during development and agerelated changes in binding capacity were associated with similar changes in cAMP-dependent histone kinase activity. Both $\left.{ }^{3} \mathbf{H}\right]$ cAMP binding and cAMP-dependent protein kinase activity decreased slightly before birth, reached maximal activity during the suckling period, and decreased in adulthood.

cAMP enhanced histone kinase activity in rat lung cytosol at all ages studied, from day 18 of gestation to adulthood. cAMP also specifically enhanced phosphorylation of several endogenous cytosolic proteins that were identified by autoradiography after sodium dodecyl sulfate-polyacrylamide gel electrophoresis. Major proteins whose phosphorylation was selectively enhanced by cAMP or inhibited by protein kinase inhibitor were approximately $\mathrm{Mr}=260,000,240,000,97,000,56,000,44,000$, and 28,000 . cAMP-dependent phosphorylation of lung cytosolic proteins was compared to that in cytosol from purified rat Type II epithelial cells. $M r=44,000$, the most prominent cAMP-dependent phosphoprotein identified in cytosol from adult lung, comigrated with the major cAMP-dependent phosphoprotein from rat Type II epithelial cells. In lung cytosol, phosphorylation of $\mathrm{Mr}=44,000$ increased dramatically during perinatal development. Phosphorylation of several other major phosphoproteins changed with age, primarily in the perinatal period.

Maturation of pulmonary function has been associated previously with marked changes in $\beta$-adrenergic receptors and catecholamine-sensitive adenylate cyclase activity which mediate the synthesis of cAMP in lung tissues. cAMP activates protein kinases that catalyze the phosphorylation of regulatory proteins by altering their activity and function. The present work demonstrates developmental changes in cAMP-dependent protein kinase activity and marked ontogenic changes in phosphorylation of several cytosolic lung proteins. Ontogenic changes in specific protein substrates of protein kinases and changes in their state of phosphorylation in response to cAMP are likely to mediate developmental changes in pulmonary responses to hormonal stimulation.
Abbreviations

Bmax, binding capacity

cAMP-PK, 3',5' cyclic adenosine monophosphate dependent protein kinase

cGMP, 3', 5' cyclic guanosine monophosphate

$I_{50}$, concentration to inhibit activity by $\mathbf{5 0 \%}$

$K_{D}$, dissociation constant

$\mathrm{Mr}$, relative migration (daltons)

PKI, protein kinase inhibitor

PMSF, phenylmethylsulfonyl fluoride

SDS-PAGE, sodium dodecyl sulfate-polyacrylamide gel electrophoresis

STE, $250 \mathrm{mM}$ sucrose, $10 \mathrm{mM}$ Tris- $\mathrm{HCl}$ (pH 7.2), and $1 \mathrm{mM}$ EGTA

TCA, trichloroacetic acid

Catecholamines regulate smooth muscle tone, surfactant release, and lung fluid secretion in the lung by stimulation of cAMP synthesis in pulmonary cells $(9,5,26)$. Effects of cAMP are mediated by cAMP-PK that are activated when cAMP binds to their regulatory subunits (Type I or II), which thereby releases catalytic subunits. Catalytic subunits phosphorylate amino acid residues of various regulatory proteins. A variety of hormone responses are known to be associated with cAMP-dependent protein phosphorylation including regulation of smooth, skeletal, and cardiac muscle contraction, glycogen metabolism and secretory processes of target cells (31). cAMP-, cGMP-, and $\mathrm{Ca}^{2+}$ dependent protein kinases have been identified previously in lung preparations from cow, rat, and mouse lung $(8,18,19,23$, 24). Although postnatal changes in characteristics of cAMP-PK have been demonstrated in mouse lung with the photoaffinity label, $8-\mathrm{N}_{3}-\left[{ }^{32} \mathrm{P}\right] \mathrm{cAMP}$, the characteristics of cAMP-PK and its possible protein substrates have not been identified extensively or characterized in mammalian lung during perinatal development (23).

Developmental changes in cAMP-dependent regulatory processes in lung are associated with dramatic changes in lung structure and function during the perinatal period. Exposure of the fetus to cAMP phosphodiesterase inhibitors or $\beta$-adrenergic agonists has been associated with increased surfactant release, reduced surface tension in lungs of experimental animals, and decreased incidence of hyaline membrane disease in prematurely born infants $(2,13,16,17,21)$. Marked changes also occur in humoral and cellular components that mediate the effects of $\beta$ adrenergic agents on the lung during development. Serum catecholamines increase during birth and pulmonary tissue catecholamines increase during development in the rat $(12,34) . \beta$ Adrenergic receptors increase prenatally and postnatally in mammalian lung $(14,37,38)$. Likewise, pulmonary catecholamineand prostaglandin-sensitive adenylate cyclase activities increase in the perinatal period in rat and rabbit lung $(1,28,30,37,38)$. Because perinatal maturation of lung function is associated with changes in responses of the lung to catecholamines and cAMP, 
we have partially characterized developmental changes in cAMPdependent protein kinase activity in lung cytosol.

\section{MATERIALS AND METHODS}

Membrane and cytosolic fractions were prepared from lungs obtained from time-dated pregnant Sprague Dawley rats purchased from Charles River, Inc. (Willmington, MA). Dams were kept on a 12-h light-dark cycle and delivered routinely at 22 days of gestation. Dams were sacrificed by cervical dislocation, the fetuses or pups were weighed and sacrificed by decapitation. Lung tissue was rapidly dissected free from hilar and mediastinal structures. Prenatal samples were pooled from each litter. Postnatal samples were pooled from two to four rat pups at each age and adult preparations were obtained from individual animals. Lung was placed in iced STE with and without $0.1 \mathrm{mM}$ phenylmethylsulfonyl fluoride and homogenized with a Tekmar Tissuemizer by three 5 -sec bursts at high setting. The homogenate was filtered through four layers of gauze and centrifuged for 5 min at $3000 \times g$ at $4^{\circ} \mathrm{C}$. This supernatant was centrifuged 40,000 $\times g$ for $20 \mathrm{~min}$ to obtain crude membranes. The resulting supernatant was centrifuged for $45 \mathrm{~min}$ at $100,000 \times g$. The final supernatant (cytosol) was assayed immediately or was frozen in a dry ice-acetone bath and stored at $-70^{\circ} \mathrm{C}$ before use. Storage did not alter either $\left[{ }^{3} \mathrm{H}\right] \mathrm{cAMP}$ binding or protein kinase activity for several months.

Type II epithelial cells. Monolayers of Type II epithelial cells were prepared as described by Brown and Longmore (5) and used after $36 \mathrm{~h}$ in tissue culture. Cells were washed in iced STE containing $0.1 \mathrm{mM}$ PMSF, scraped with a rubber policeman, and homogenized by sonication. Cell cytosol was prepared by centrifugation as described for cytosolic preparations of lung samples. Phosphorylation was performed on freshly prepared cytosol. Cultures contained a homogeneous population of Type II epithelial cells, generally greater than $90 \%$ viable Type II cells as assessed by trypan blue exclusion, phosphine $3 \mathrm{R}$ fluorescence and phase contrast microscopy.

$\left[^{3} \mathrm{H}\right] \mathrm{cAMP}$ binding. Regulatory subunits of cAMP-dependent protein kinase(s) were characterized by the binding of $\left[{ }^{3} \mathrm{H}\right] \mathrm{cAMP}$, $26 \mathrm{Ci} / \mathrm{mmole}$ (New England Nuclear) to cytosolic and membrane fractions as described by Corbin et al. (8). Lung protein was determined by the method of Lowry et al. (22) using bovine serum albumin as standard. Approximately $40-60 \mu \mathrm{g}$ of protein was incubated for $90 \mathrm{~min}$ at $4^{\circ} \mathrm{C}$ in buffer containing $40 \mathrm{mM}$ sodium acetate ( $\mathrm{pH} 4.0$ ) and $0.4-80 \mathrm{nM}\left[{ }^{3} \mathrm{H}\right] \mathrm{cAMP}$ in triplicate $200 \mu \mathrm{l}$ assays. Incubations were terminated by addition of $1 \mathrm{ml}$ of saturated $\left(\mathrm{NH}_{4}\right)_{2} \mathrm{SO}_{4}, 10^{-6} \mathrm{M}$ adenosine monophosphoric acid, $10 \mathrm{mM}$ potassium phosphate buffer ( $\mathrm{pH} \mathrm{6.0)}$ ), and then rapidly filtered under negative pressure on HAWP filters (Millipore). Filters were washed five times with $4 \mathrm{ml}$ of iced $20 \mathrm{mM}$ potassium phosphate buffer ( $\mathrm{pH} \mathrm{6.0)}$ ), dried, and radioactivity determined by standard scintillation technique at $40 \%$ efficiency. Nonspecific binding was determined in the presence of $100 \mu \mathrm{M}$ cAMP and was less than $2 \%$ of the total binding near the $\mathrm{K}_{\mathrm{D}}$ for $\left[{ }^{3} \mathrm{H}\right]$ cAMP. Specific binding increased in direct proportion to added cytosolic protein, 10-100 $\mu \mathrm{g}$. Although the binding appeared to occur to a single class of sites, $B$ max and $K_{D}$ were determined by Scatchard analysis of binding data with seven to nine concentrations of $\left[{ }^{3} \mathrm{H}\right]$ cAMP (33). Affinity of competing ligands for inhibition of $\left[{ }^{3} \mathrm{H}\right] \mathrm{cAMP}$ binding was determined from the $\mathrm{I}_{50}$ as described by Cheng and Prusoff (7). Statistical differences among age groups were assessed by analysis of variance with NeumannKuels test.

To separate regulatory subunits, lung cytosol was fractionated on a DEAE-cellulose column as described by Corbin et al. (8) except that an $\left(\mathrm{NH}_{4}\right)_{2} \mathrm{SO}_{4}$ gradient was used to elute the column. Approximately $20 \mathrm{mg}$ of protein was applied to a $1.5 \times 10 \mathrm{~cm}$ column equilibrated with $10 \mathrm{mM} \beta$-mercaptoethanol and 10 $\mathrm{mM}$ Tris- $\mathrm{HCl}(\mathrm{pH} 7.0)$ and eluted with a linear gradient of $(0-$ $0.3 \mathrm{M})\left(\mathrm{NH}_{4}\right)_{2} \mathrm{SO}_{4}$. Column fractions $(1.2 \mathrm{ml})$ were collected and assayed for specific $\left[{ }^{3} \mathrm{H}\right] \mathrm{cAMP}$ binding, conductivity, and protein.
Protein kinase and phosphorylation. Protein kinase was assessed in triplicate $200-\mu l$ assays in the presence of cytosol or membrane protein $(40-80 \mu \mathrm{g})$ in buffer containing $9 \mathrm{mM} \mathrm{NaF}$, $9 \mathrm{mM} \mathrm{MgCl}_{2}$, and $45 \mathrm{mM}$ potassium phosphate, $\mathrm{pH} 7.0 ; 1 \mathrm{mg} /$ $\mathrm{ml}$ Type II A histone with and without $10 \mu \mathrm{M}$ cAMP or $0.2 \mathrm{mg} /$ $\mathrm{ml}$ protein kinase inhibitor $(15,35)$. In general, phosphorylation, in presence or absence of PKI, were identical. Phosphorylation was initiated by addition of $\gamma\left[{ }^{32} \mathrm{P}\right]$ ATP (New England Nuclear) to give a final assay concentration of $0.5 \mathrm{mM} \mathrm{ATP}$, approximately $20 \mu \mathrm{Ci} / \mathrm{mmole}$. Assays were incubated at $30^{\circ} \mathrm{C}$ for $10 \mathrm{~min}$ and were terminated by addition of $50 \mu \mathrm{l}$ of $2.5 \%$ bovine serum albumin with $0.02 \%$ deoxycholate followed by $2.5 \mathrm{ml}$ of iced $2.5 \%$ TCA. The sample was filtered on glass fiber filters (Whatman, Inc., Clifton, $\mathrm{NJ}$ ) that were presoaked in $2.5 \%$ sodium pyrophosphate in $10 \%$ TCA. Filters were washed three times with $4 \mathrm{ml}$ iced $2.5 \%$ TCA. Filters were dried and counted by standard scintillation technique.

Protein phosphorylation in samples to be separated by polyacrylamide gel electrophoresis was initiated by addition of $\left.\gamma{ }^{32} \mathrm{P}\right]$ ATP (approximately $2 \mathrm{mCi} / \mathrm{mmole}$ ) to give a final concentration of $5 \mu \mathrm{M}$ ATP. Phosphorylation was tested in presence and absence of $10 \mu \mathrm{M}$ cAMP or $0.2 \mathrm{mg} / \mathrm{ml}$ cAMP PKI. At least three separate experiments were performed at each age. Both potassium phosphate and a $10 \mathrm{mM}$ Tris- $\mathrm{HCl}(\mathrm{pH} 7.4), 1 \mathrm{mM}$ EGTA, $\mathrm{CaCl}_{2}$ buffer system were utilized, the latter to control free $\mathrm{Ca}^{2+}$ to $10^{-5}$ iM as described by Piascik et al. (29).

Ontogenic changes in phosphorylation patterns determined after polyacrylamide gel electrophoresis were assessed in experiments with identical amounts of protein from preparations at each age. Assays were performed on the same day and gels were placed on X-ray film for an identical amount of time. Phosphorylation reactions were incubated at $30^{\circ} \mathrm{C}$ and terminated after 6 min by precipitation with iced $12 \%$ TCA. The samples were washed by repeated centrifugation and pellets solubilized in sodium dodecyl sulfate $(20,32)$. Electrophoresis was routinely performed at $20 \mathrm{~mA}$ per gel for $1.5 \mathrm{~h}$ on a $4.3 \%$ SDS-polyacrylamide stacking gel followed by electrophoresis at $30 \mathrm{~mA}$ per gel for $2 \mathrm{~h}$ on $7.5 \%, 10 \%$, or $12.5 \%$ SDS-polyacrylamide separating gels. Addition of protease inhibitor, PMSF, and use of frozen cytosolic preparations did not significantly alter protein phosphorylation patterns of major proteins. Phosphorylation in Type II cells was determined as above except that fresh preparations of cytosol were routinely utilized.

Protein phosphorylation was dependent upon time, reaching maximal incorporation at approximately $6-10 \mathrm{~min}$. Phosphorylation increased in relation to cytosolic protein and was completely removed from the gels by pretreatment of the samples with trypsin or $100 \mathrm{mM} \mathrm{NaOH}$ at $95^{\circ} \mathrm{C}$ for $20 \mathrm{~min}$. Phosphoproteins were unaltered by extraction in 2:1 chloroform:methanol, acidified $(0.01 \mathrm{M} \mathrm{HCl})$ chloroform:methanol, treatment with hydroxylamine or heating to $90^{\circ} \mathrm{C}$ in $2 \%$ TCA. Gels were fixed, stained in $0.25 \%$ Coomassie brilliant blue and dried as described by Rudolph and Krueger (32). Gels were placed on Kodak XAR2 film for 1-7 days, depending on the extent of phosphorylation. Molecular weights were estimated using rabbit muscle phosphorylase b $(97,000)$, bovine serum albumin $(66,000)$, rat brain tubulin $(56,000)$, bovine heart cAMP protein kinase $(56,000)$, ovalbumin $(45,000)$, pepsin $(35,000)$, and trypsinogen $(24,000)$ (Sigma Chemical Co., St. Louis, MO). Phosphorylation was assessed visually and by scanning densitometer.

Statistical differences in protein kinase activity among various age groups were determined by analysis of variance with the Neumann-Kuels test. Significance of the activation of basal protein kinase activity by cAMP was determined by paired $t$ test. Significance is reported at $P<0.05$.

\section{RESULTS}

$\left[{ }^{3} \mathrm{H}\right] \mathrm{CAMP}$ binding. $\left[{ }^{3} \mathrm{H}\right] \mathrm{CAMP}$ binding activity was associated primarily with lung cytosol during subcellular fractionation. Specific activity of binding to washed particulate membranes was less than $10 \%$ of specific activity present in cytosol. Specific 
RAT LUNG CYTOSOL C-AMP BINDING
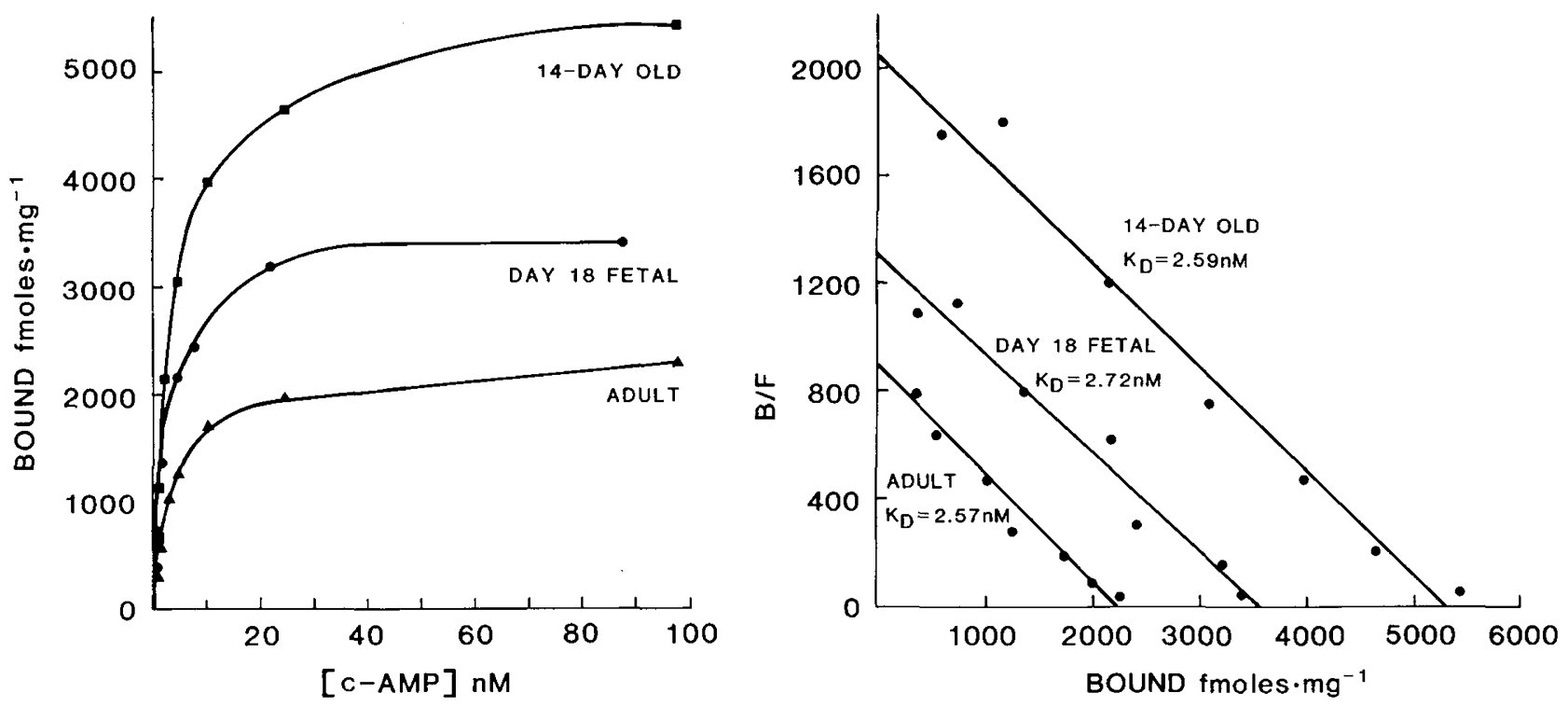

Fig. 1. Respresentative saturation experiments and Scatchard analyses of $\left[{ }^{3} \mathrm{H}\right] \mathrm{cAMP}$ binding to rat lung cytosol on day 18 of gestation, postnatal day 14 , and adulthood. $\left[{ }^{3} \mathrm{H}\right] \mathrm{cAMP}$ binding to lung cytosol was assessed by filtration assay as described in "Materials and Methods." Binding was determined in triplicate in the presence and absence of $10 \mu \mathrm{M}\left[{ }^{3} \mathrm{H}\right] \mathrm{cAMP}$ to determine specific binding. Binding capacity, but not affinity, changed significantly with age. B/F represents $\mu$ liter/mg protein.

ADULT RAT LUNG

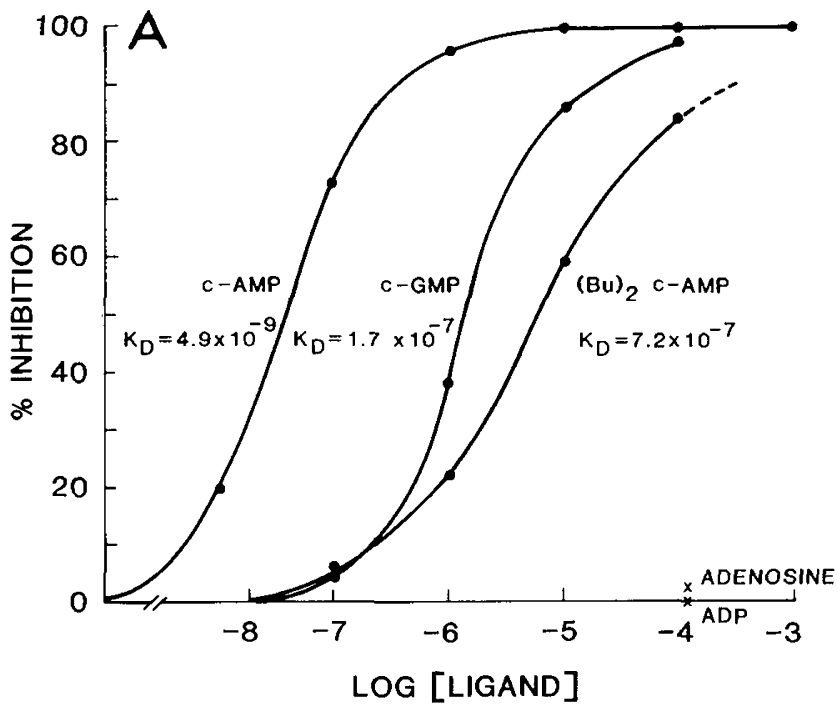

FETAL RAT LUNG

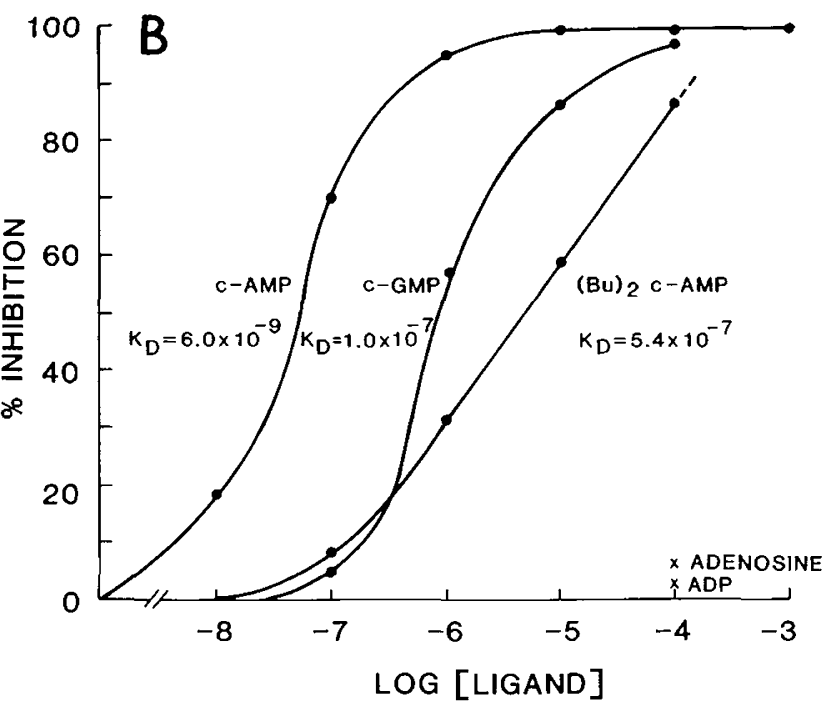

Fig. 2. Specificity of $\left[{ }^{3} \mathrm{H}\right] \mathrm{cAMP}$ binding to rat lung cytosol. The inhibition of $\left[{ }^{3} \mathrm{H}\right] \mathrm{cAMP}$ binding to rat lung cytosol by cAMP, cGMP, dibutyryl cAMP, adenosine, ADP, and ATP was determined in preparations from rat pups at 20 days gestation and adults. $\left[{ }^{3} \mathrm{H}\right] \mathrm{CAMP}$ binding was assessed in triplicate at $20 \mathrm{nM}\left[{ }^{3} \mathrm{H}\right] \mathrm{CAMP}$ and increasing concentrations of the nucleotides $\left(10^{-10}\right.$ to $\left.10^{-3} \mathrm{M}\right)$. ATP did not inhibit binding (data not shown).

$\left[{ }^{3} \mathrm{H}\right]$ cAMP binding to lung cytosol increased in relation to increasing protein concentration and was time-dependent, reaching equilibrium by $60 \mathrm{~min}$ at the lowest ligand concentration $(0.4$ $\mathrm{nM})$. Saturation experiments and Scatchard analysis of $\left[{ }^{3} \mathrm{H}\right] \mathrm{cAMP}$ binding to lung cytosol are represented by Figure 1. By Scatchard analysis, binding appeared to occur to a single class of sites, $K_{D}=2-3 \mathrm{nM}$; however, experiments describing the rate of dissociation of $\left[{ }^{3} \mathrm{H}\right] \mathrm{cAMP}$ from cytosolic binding sites resulted in a complex dissociation curve suggesting the presence of either heterogeneity or cooperativity of binding sites (not shown).

Inhibition of specific $\left[{ }^{3} \mathrm{H}\right] \mathrm{cAMP}$ binding by other nucleotides followed this order of potency: cAMP $>$ cGMP $>$ dibutyryl cAMP (Fig. 2). Adenosine, ADP, and ATP $\left(10^{-3} \mathrm{M}\right)$ did not compete for $\left[{ }^{3} \mathrm{H}\right] \mathrm{cAMP}$ binding sites. The number of binding sites determined from saturation experiments (Bmax) varied slightly during development from 18 days of gestation to adulthood. $\left[{ }^{3} \mathrm{H}\right] \mathrm{cAMP}$ binding increased significantly during the neonatal period from $3060 \pm 474 \mathrm{fmole} \cdot \mathrm{mg}^{-1}$ protein on days 20 21 of gestation to $4840 \pm 478 \mathrm{fmole} \cdot \mathrm{mg}^{-1}$ at 14 days of age, mean \pm S.E., $P<0.01$ (Table 1). Binding activity decreased significantly after 14 days of age to adult levels, $2650 \pm 203$ fmole $\cdot \mathrm{mg}^{-1}$ protein, $P<0.01$. Affinity of $\left[{ }^{3} \mathrm{H}\right] \mathrm{cAMP}$ binding to lung cytosol did not vary significantly with age.

Regulatory subunits of cAMP-dependent protein kinases in rat lung cytosol were separated by DEAE-cellulose chromatography using a linear $\left(\mathrm{NH}_{4}\right)_{2} \mathrm{SO}_{4}$ gradient. Two peaks of specific $\left[{ }^{3} \mathrm{H}\right]$ cAMP binding were demonstrated in these preparations at all ages as shown by Figure $3 .\left[{ }^{3} \mathrm{H}\right]$ cAMP binding activity eluted 
Table 1. Ontogeny of $\left[{ }^{3} \mathrm{H}\right] \mathrm{CAMP}$ binding and cAMP-dependent histone kinase activity in rat lung cytosol from 18 days gestation to adulthood $^{1}$

\begin{tabular}{|c|c|c|c|c|c|c|}
\hline Age & $\begin{array}{l}{\left[{ }^{3} \mathrm{H}\right] \mathrm{cAMP} \text { bound fmole. }} \\
\mathrm{mg}^{-1}\end{array}$ & $\mathrm{~K}_{\mathrm{D}}(\mathrm{nM})$ & $n$ & $\begin{array}{c}\text { cAMP-dependent histone } \\
\text { kinase }\left(\mathrm{pmole} \cdot \mathrm{mg}^{-1} \cdot 10 \mathrm{~min}^{-1}\right)\end{array}$ & $\begin{array}{l}\text { Activation ratio } \\
\frac{\text { No cAMP }}{10 \mu \mathrm{M} \mathrm{cAMP}}\end{array}$ & $n$ \\
\hline 18-day fetal & $3740 \pm 207^{5}$ & $2.64 \pm 0.39$ & (6) & $4620 \pm 352^{2}$ & $0.46 \pm 0.02^{2}$ & (7) \\
\hline Newborn & $2320 \pm 38^{4}$ & $1.68 \pm 0.15$ & (3) & $2770 \pm 119^{3}$ & $0.40 \pm 0.02$ & (4) \\
\hline $5-6$ days & $3480 \pm 234^{5}$ & $1.82 \pm 0.26$ & (6) & $3930 \pm 341$ & $0.37 \pm 0.01$ & (5) \\
\hline 14 days & $4840 \pm 478^{2}$ & $2.30 \pm 0.41$ & (6) & $4780 \pm 243^{2}$ & $0.34 \pm 0.02$ & (5) \\
\hline
\end{tabular}

${ }^{1}$ Binding capacity and affinity for $\left[{ }^{3} \mathrm{H}\right]$ cAMP binding were determined from Scatchard analyses of saturation experiments with 7-9 concentrations of $\left.{ }^{3} \mathrm{H}\right]$ CAMP. cAMP-dependent histone kinase was also determined in triplicate in each preparation. Statistical differences among various ages were assessed by analysis of variance with Neumann-Kuels test, $P<0.05$. Values are mean \pm S.E. and $n$, number of preparations.

${ }^{2}$ Greater than adult, $P<0.01$

${ }^{3}$ Less than 18-day fetal, $P<0.01$

${ }^{4}$ Less than 14-day, $P<0.01$

${ }^{5}$ Less than 14-day, $P<0.05$

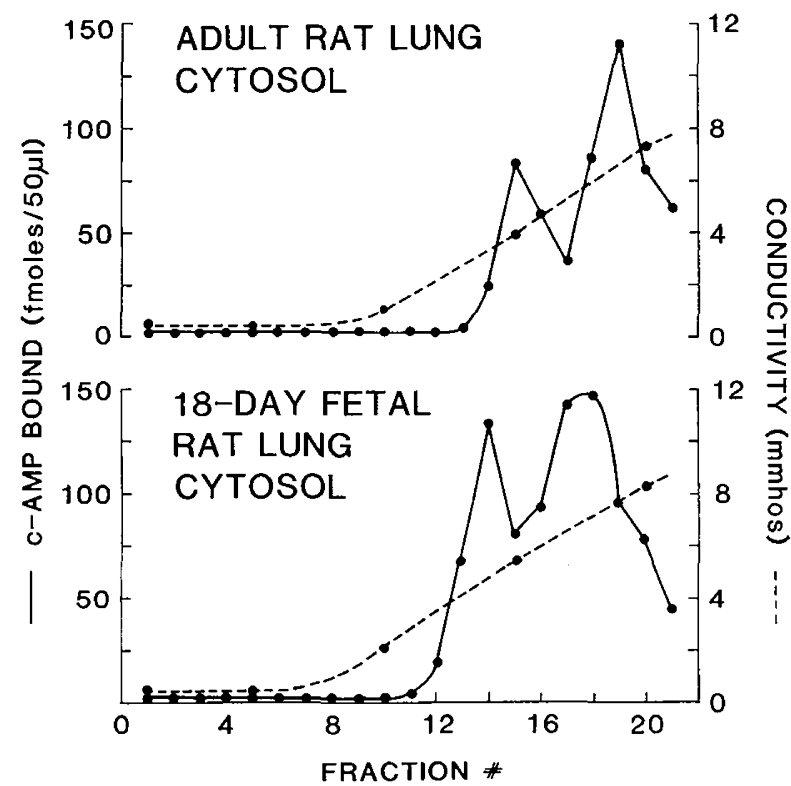

Fig. 3. DEAE-cellulose chromatography of $\left[{ }^{3} \mathrm{H}\right] \mathrm{CAMP}$ binding activity to fetal and adult lung cytosol. Proteins were separated in a $1.5 \times 10$ $\mathrm{cm}$ column by elution with a linear $\left(\mathrm{NH}_{4}\right)_{2} \mathrm{SO}_{4}$ gradient as described in "Materials and Methods." Specific $\left[{ }^{3} \mathrm{H}\right] \mathrm{cAMP}$ binding was assessed in each fraction at $20 \mathrm{nM}\left[{ }^{3} \mathrm{H}\right] \mathrm{cAMP}$. Conductivity was assessed in each fraction $(1.2 \mathrm{ml})$.

at 4.0-4.5 mmhos and 6.5-7.5 mmhos, typical of Type I and Type II regulatory subunits respectively. There were no changes in elution patterns of the regulatory subunits between samples obtained at 18 days gestation and adulthood.

Protein kinase activity. cAMP-dependent protein kinase activity and protein kinase activity ratios were demonstrated in lung cytosol during development from day 18 of gestation to adulthood (Table 1 and Fig. 4). Most cAMP-dependent protein kinase activity was associated with lung cytosol when determined by filter assay. cAMP significantly increased histone kinase activity at all ages studied. $\mathrm{I}_{50}$ for activation of histone kinase by cAMP was approximately $0.1 \mu \mathrm{M}$. cAMP-dependent protein kinase activity, like $\left[{ }^{3} \mathrm{H}\right]$ cAMP binding activity, decreased before birth, increased significantly during the weanling period, and thereafter decreased to adult levels (Table 1 and Fig. 4). Activity ratios (activity - cAMP):(activity + cAMP) varied from $0.34-0.46$. Activity ratio was slightly higher in samples on day 18 of gestation and did not change significantly with age thereafter. Histone phosphatase activity was determined in lung cytosol by chase

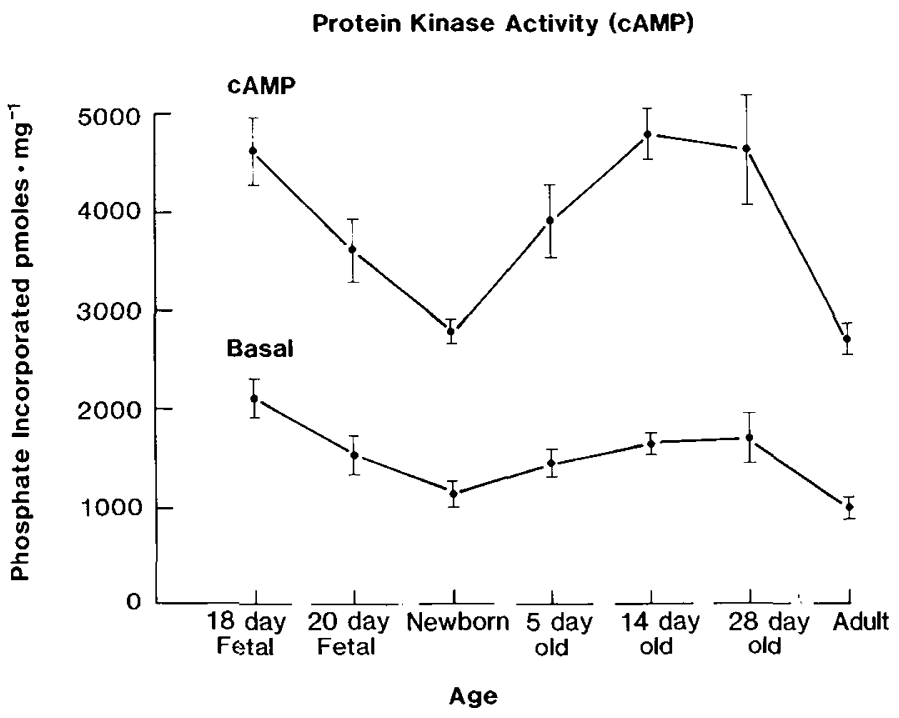

Fig. 4. Ontogeny of cAMP-dependent histone kinase activity in rat lung cytosol from rats on day 18 of gestation to adulthood. Histone kinase activity was determined in triplicate in the presence and absence of $10 \mu \mathrm{M}$ cAMP in four to seven preparations at each age. Values represent pmole/mg protein per $10 \mathrm{~min}$. cAMP significantly enhanced basal activity, $P<0.01$ at all ages. CAMP-dependent protein kinase activity decreased significantly in late gestation, increased significantly to maximal concentration on day 14 of age and was decreased significantly in the adult as assessed by analysis of variance with NeumannKuels test.

experiments initiated by addition of excess unlabeled ATP ( 1 $\mathrm{mM}$ ) to phosphorylated histone. The time-related decrease in labeled phosphoprotein was quantitated by filtration assay. The half-life for the dephosphorylation reaction was approximately $15 \mathrm{~min}$ in both fetal and adult cytosolic preparations under usual assay conditions.

cAMP-dependent phosphorylation of endogenous lung proteins. Phosphorylation of endogenous lung protein was greater in cytosol than in membrane preparations. When membrane was added to labeled cytosol, the amount of phosphorylation present on the gel was slightly decreased. Autoradiograms of phosphoproteins from lung cytosol obtained from fetuses on day 20 of gestation and from adults are represented by Figure 5. In general, endogenous phosphorylation of cytosolic protein was less in adult than in neonatal samples. Endogenous phosphorylation in fetal and neonatal preparations was similar except for age-related changes in specific phosphoproteins. Of the many phosphoryl- 


\section{LUNG CYTOSOL}

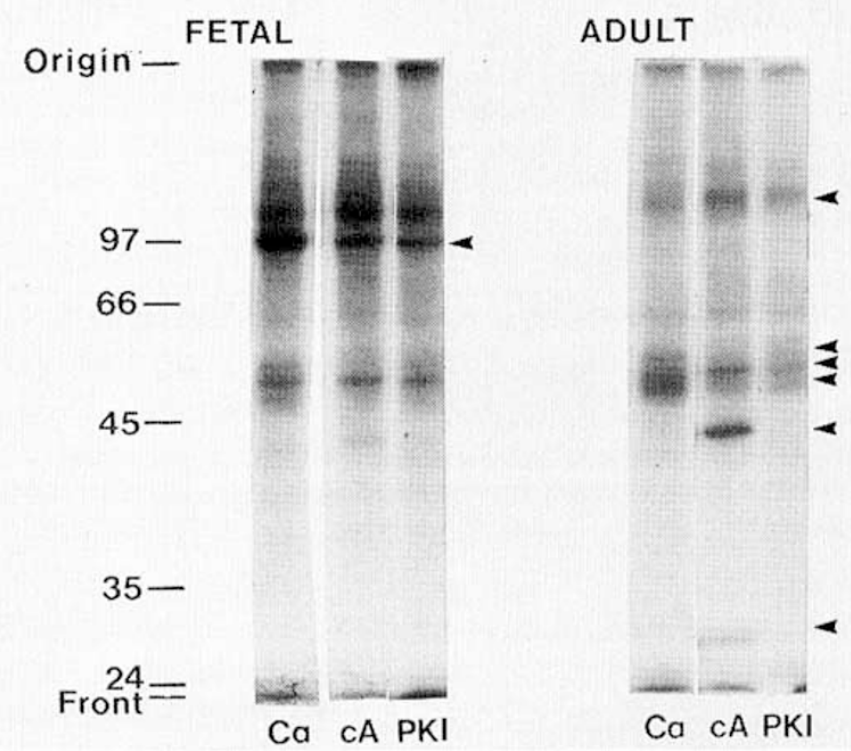

Fig. 5. Autoradiogram of phosphoproteins in lung cytosol from fetal (day 20 of gestation) and adult rats. Phosphorylation was performed with $20 \mu \mathrm{g}$ of fetal and adult lung cytosol in the presence of $10 \mu \mathrm{M} \mathrm{Ca}^{2+}$, cAMP or $0.2 \mathrm{mg} / \mathrm{ml}$ protein kinase inhibitor and separated by $10 \%$ SDSPAGE followed by autoradiography as described in the "Materials and Methods." The numbers 97-24 represent 97,000-24,000-dalton marker proteins used for standards. Major proteins whose phosphorylation was enhanced by CAMP and inhibited by protein kinase inhibitors or clearly ontogenically regulated are marked by arrows at approximately 110,000 , $97,000,54-58,000,44,000$, and 28,000 daltons.

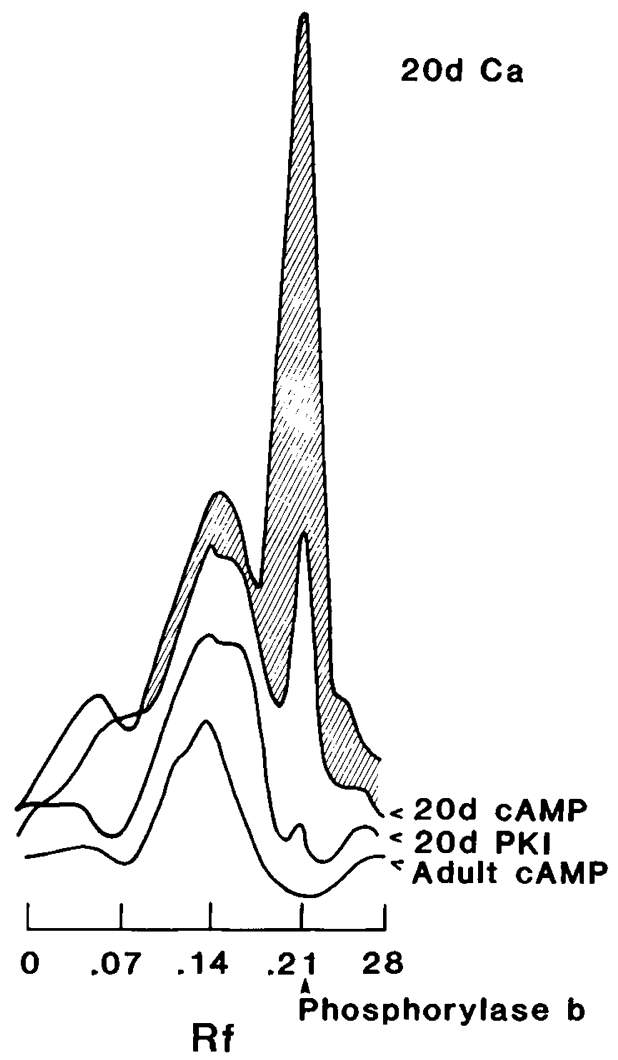

Fig. 6. Scan of autoradiograms of phosphoproteins migrating with $R_{f}$ $0-0.18$ on $7.5 \%$ SDS-polyacrylamide gels. cAMP-dependent phosphorylation of lung cytosol $(20 \mu \mathrm{g})$ was assessed in the presence of $10 \mu \mathrm{M}$ ated proteins present in cytosolic preparations, several were clearly enhanced by CAMP. Major proteins whose phosphorylation was stimulated by cAMP were detected at $\mathrm{Mr}=260,000$, $240,000,97,000,56,000,44,000$, and 28,000 daltons. Their detectability varied with age (Fig. 5). There were also distinct age-related differences in the patterns of cAMP independent phosphoproteins as can be seen in Figure 5.

Phosphorylation of 97,000-dalton protein was slightly enhanced by CAMP and its phosphorylation was more dependent upon $\mathrm{Ca}^{2+}$ than cAMP (Fig. 6). This protein comigrated with rabbit muscle phosphorylase $b$ and its phosphorylation appears to be highly ontogenically regulated (Figs. 5 and 6). The 97,000dalton phosphoprotein was barely detectable on day 17 but increased by day 18 of gestation. It was the most prominent phosphoprotein between days 19 and 21 of gestation, representing approximately $10 \%$ of the total phosphoprotein on the gel. Phosphorylation of the 97,000 -dalton protein decreased dramatically postnatally and was nearly undetectable by 5 days of age through adulthood. Phosphorylation of protein migrating 110 120,000 daltons was not clearly cAMP-dependent. $\mathrm{Mr}=110$ 120,000 phosphoproteins were greater in fetal than postnatal samples, decreasing markedly in the perinatal period.

Phosphorylation of $\mathrm{Mr}=260,000,240,000$ (not seen), 56,000, 44,000 , and 28,000 was also enhanced by cAMP (Figs. 5 and 7 ). cAMP-dependent phosphorylation of 28,000 and 44,000 dalton proteins was first detected in late gestation and was readily apparent thereafter to adulthood. cAMP enhanced phosphorylation of protein migrating at 56,000 daltons which comigrated with rat brain tubulin (Fig. 7); however, its identity remains to be established. Phosphorylation of the 56,000 dalton-protein

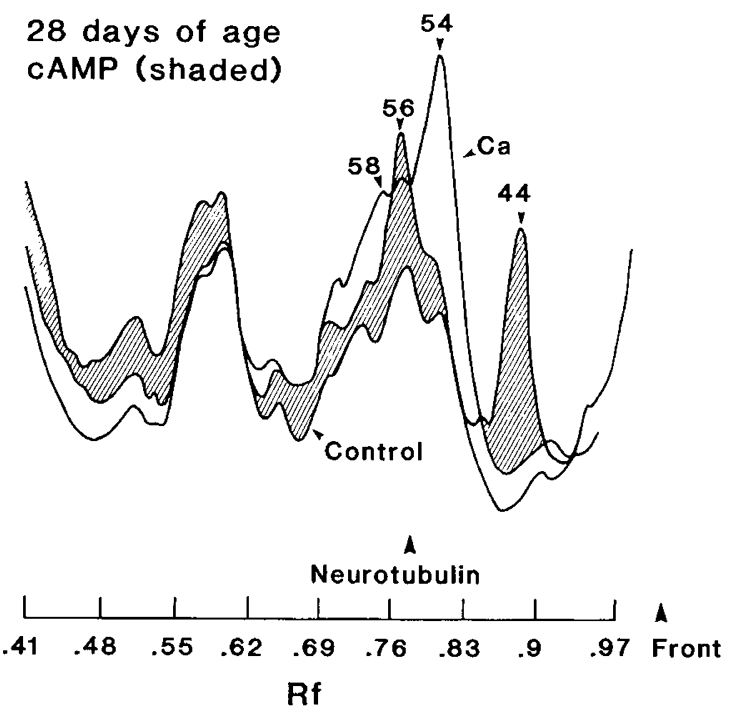

Fig. 7. Scan of autoradiogram of phosphoprotein migrating with $R_{f}$ $=0.41-1.0$ on $7.5 \%$ SDS-PAGE from lung cytosol obtained at 28 days of age. Phosphorylation was determined in the presence of $20 \mu \mathrm{g}$ cytosol with or without $10 \mu \mathrm{M}$ cAMP and $10 \mu \mathrm{M}$ free $\mathrm{Ca}^{2+}$ in a $1 \mathrm{mM}$ EGTA buffer system (29). The shaded area represents phosphorylation in the presence of cAMP. The 56,000-dalton peak comigrated with rat brain tubulin.

cAMP or $0.2 \mu \mathrm{g} / \mathrm{ml}$ protein kinase inhibitors on day 20 of gestation and adult as described in the "Materials and Methods" in the presence of contaminating $\mathrm{Ca}^{2+}$ in $20 \mathrm{mM}$ potassium phosphate buffer and $5 \mu \mathrm{M}$ $\gamma\left[{ }^{32} \mathrm{P}\right] \mathrm{ATP} . \mathrm{Ca}^{2+}$-dependent phosphorylation (shaded area) was determined in a Tris-EGTA buffer system ( $1 \mathrm{mM}$ EGTA) and $\mathrm{CaCl}_{2}$ to give calculated free $\mathrm{Ca}^{2+}=10 \mu \mathrm{M}$ (29). Neither cAMP nor $\mathrm{Ca}^{2+}$ enhanced the phosphorylation of protein with $R_{f}$ of 0.21 in the adult. Rabbit muscle phosphorylase $b$ comigrated with the peak with $R_{f}=0.21$. This phosphoprotein was not detectable in samples obtained at $5,14,28$ days of age or adulthood. 


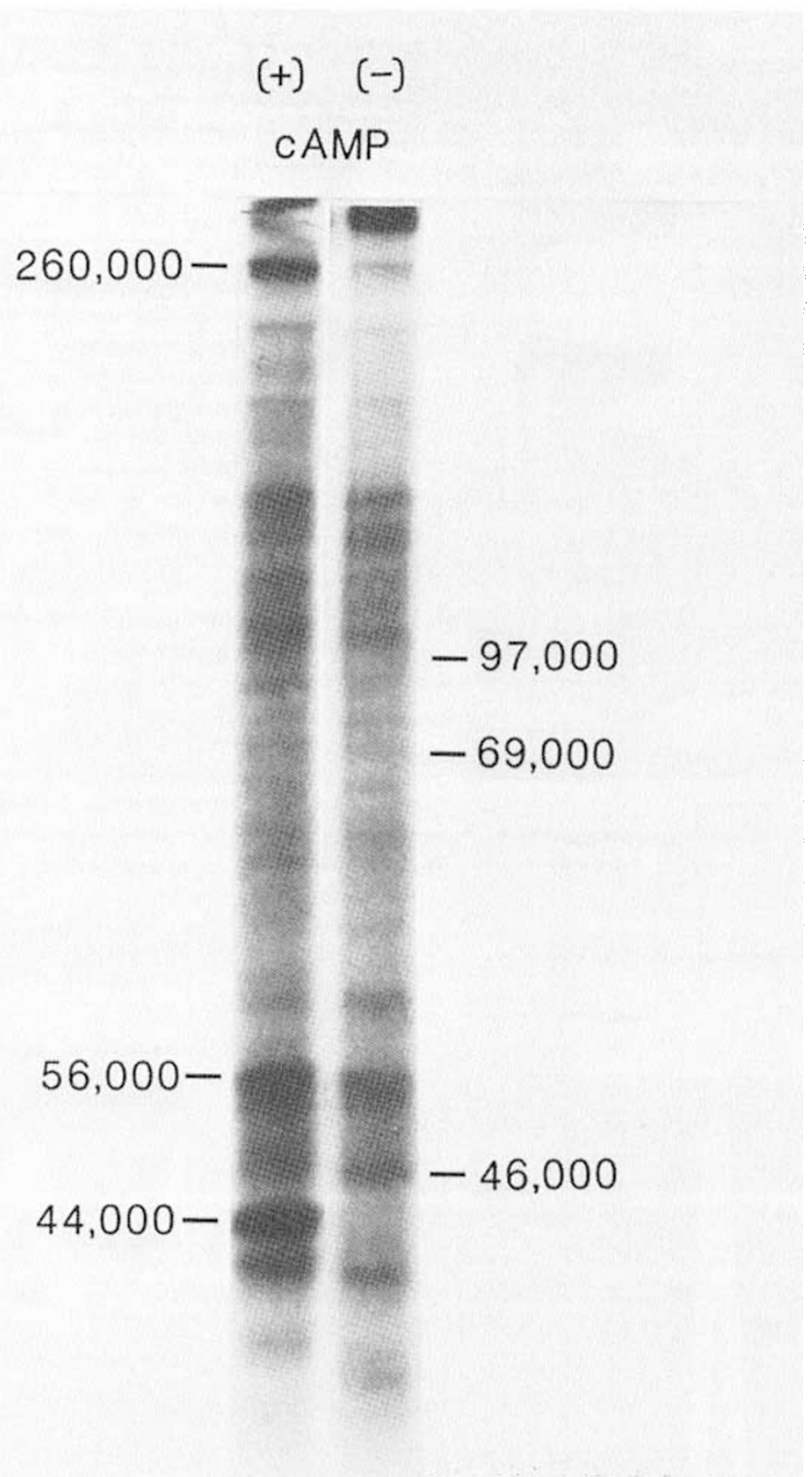

Fig. 8. Autoradiography of major Type II epithelial cell phosphoproteins. Phosphorylation of $10 \mu \mathrm{g}$ cytosolic protein was performed in the presence (+) and ( - ) absence of $10 \mu \mathrm{M}$ cAMP and separated by $8 \%$ SDS-PAGE. Autoradiography was performed for 2 days at room temperature. cAMP enhanced phosphorylation of $\mathrm{Mr}=260,000,240,000,44,000$, and 22,000. The band migrating with $\mathrm{Mr}=22,000$ is not visualized on this gel however.

increased only slightly during the perinatal period. Phosphorylation of the 54,000- and 58,000-dalton protein was primarily $\mathrm{Ca}^{2+}$-dependent. None of the phosphoproteins comigrated with autophosphorylated Type II cAMP-dependent protein kinase from bovine heart.

cAMP enhanced phosphorylation of several Type II cell proteins with characteristics similar to phosphorylation in crude lung cytosol. The major cAMP-dependent proteins from Type II cells migrated approximately $\mathrm{Mr}=260,000,240,000,44,000$, and 22,000. $\mathrm{Mr}=44,000$ daltons was the most prominent cAMPdependent phosphoprotein in Type II cell cytosol (Fig. 8) and comigrated with $\mathrm{Mr}=44,000$ from adult lung cytosol.

\section{DISCUSSION}

Our work describes ontogenic changes in cAMP-PK and some of its protein substrates in cytosolic preparations of rat lung between 18 days gestation and adulthood. The specific activity of $\left[{ }^{3} \mathrm{H}\right] \mathrm{cAMP}$ binding to the regulatory subunits of CAMP-PK varied slightly with age: decreasing in late gestation, increasing significantly by 14 days of postnatal age, and subsequently decreasing to concentrations present in the mature adult. Affinity of $\left[{ }^{3} \mathrm{H}\right] \mathrm{cAMP}$ for regulatory subunits did not change with age. Protein kinase activity in lung cytosol was stimulated by cAMP at all ages studied. Developmental changes in cAMP-dependent protein kinase correlated with changes in $\left[{ }^{3} \mathrm{H}\right] \mathrm{cAMP}$ binding. cAMP enhanced phosphorylation of protein substrates present both in lung cytosol and in cytosol from purified Type II epithelial cells. Phosphorylation of several of these proteins changed during perinatal development.

Properties of $\left[{ }^{3} \mathrm{H}\right] \mathrm{cAMP}$ binding and of cAMP-PK in developing rat lung were similar to those reported previously in other tissues $(8,18,19,23,24)$. There were no detectable changes in the presence of the Type I or Type II regulatory subunits in lung 
cytosol between 18 days of age and adult. Although the number of cAMP binding sites determined by filter assay varied slightly during development, the affinity of CAMP for these sites did not change with age. Changes in binding capacity or affinity related to the effect of the filter on cAMP binding to regulatory subunits of cAMP-PK have been reported previously $(10)$. It is therefore possible that total cAMP binding may be underestimated with this assay system. In spite of complex dissociation kinetics of $\left[{ }^{3} \mathrm{H}\right]$ cAMP binding to lung cytosol, the Scatchard plots of saturation experiments were linear. The reasons for the linearity are unclear but similar findings have been described in a variety of tissues. Detailed analysis of dissociation experiments with regulatory subunits support the presence of two cAMP binding sites per subunit (10). It has been postulated that loss of one binding site occurs during filtration or that cooperative interactions result in the linearization of Scatchard plots. The number of binding sites determined by saturation plots are likely to represent a relative estimation of the binding activity. Ontogenic changes in binding capacity correlated well with cAMP-dependent histone kinase activity. cAMP-PK activity was previously identified in guinea pig lung where activity also increased slightly in the neonatal period (19). Our study indicates that cAMP-PK activity in rat lung decreased slightly but significantly before birth, reaching maximal activity during the weanling period and decreasing again to adulthood. The functional significance of these changes are unclear at present.

Phosphorylation of endogenous lung proteins by protein kinases has not been intensively studied to date. cAMP-dependent phosphorylation of a 49,000-dalton protein in lung cytosol was noted in a previous study and thought to be regulatory subunits of cAMP-PK (24). In our study, numerous cytosolic proteins were phosphorylated in rat lung cytosol; however, several proteins were clearly cAMP-dependent or inhibited by cAMP-dependent protein kinase inhibitor. Several commercial preparations of PKI were utilized during these studies and identical results were obtained with freshly prepared PKI from rat skeletal muscle (35). PKI was utilized because of the possibility that catalytic subunits might be activated during preparation of cytosol; however, phosphorylation in the presence of PKI was not significantly different from phosphorylation in control samples incubated in the absence of CAMP and PKI.

Phosphoproteins identified after SDS-PAGE were trypsin- and alkali-sensitive. Hydroxylamine, TCA $\left(90^{\circ} \mathrm{C}\right)$, chloroform: methanol, and acidified chloroform:methanol did not alter their phosphorylation; thus, the phosphoprotein probably represent phosphoesters rather than acylphosphate, RNA, or lipid-associated phosphate (36). Proteins migrating with molecular weights below 18,000 or greater than 300,000 daltons were not resolved in the present study. The identities of the major phosphoproteins demonstrated in lung cytosol have not been clarified at present. The most prominent phosphoprotein observed on gels from fetal lung comigrated with phosphorylase $b$, a known substrate of phosphorylase kinase (27). Phosphorylation of the $\mathrm{Mr}=97,000$ protein was clearly age-dependent. It was barely detectable at 17 days of gestation, increased markedly between 18-20 days of gestation before birth, and decreased markedly after birth. Its phosphorylation was also enhanced to a greater extent by $\mathrm{Ca}^{2+}$ than by cAMP.

Phosphorylase $\mathrm{b}$ is known to be phosphorylated and activated by phosphorylase kinase. The activation of phosphorylase kinase is $\mathrm{Ca}^{2+}$-dependent and enhanced by cAMP in other tissues (27, 36). Activity of phosphorylase a increases dramatically in late gestation in rat lung and the increase in its activity is associated with rapid glycogen depletion from pulmonary tissues $(3,4,25)$. Both phosphorylase $a$ and $b$ activities are known to decrease rapidly postnatally $(25)$. Decrease in 97,000 -dalton phosphoprotein may represent a decrease in the amount of phosphorylase a and $b$; however, decreased phosphorylase kinase or increased phosphorylase phosphatase activity might also account for the observed decrease in 97,000 dalton phosphoprotein with age.

Phosphorylation of $\mathrm{Mr}=56,000$ protein was slightly enhanced by cAMP. It comigrated with rat brain tubulin; however, this provides little evidence of its identity. cAMP phosphorylation of neurotubulin has been reported previously $(6,11)$ and the observation that colchicine inhibits CAMP-induced surfactant release from type II epithelial cells supports the hypothesis that tubulin might be involved in the mediation of cAMP dependent surfactant release process (26). Clearly the identity of $\mathrm{Mr}=56,000$ phosphoprotein has not been established in this study. Phosphorylation of 54,000- and 58,000-dalton protein was enhanced by $\mathrm{Ca}^{2+}$. Exogenous calmodulin further enhanced $\mathrm{Ca}^{2+}$-dependent phosphorylation of $\mathrm{Mr}=54,000$ (data not shown). Neither $54,000-, 56,000$-, nor 58,000-dalton phosphoproteins comigrated with autophosphorylated regulatory subunit of bovine heart protein kinase. cAMP-dependent phosphorylation of 49,000-dalton protein in lung cytosol from adult rat lung was reported previously and regulatory subunits of cAMP-protein kinase have been demonstrated previously by phosphorylation with 8 -azido $\left[{ }^{32} \mathrm{P}\right]$ cAMP in both fetal and adult mouse lung preparations. Photoaffinity labeled regulatory subunits of protein kinase from mouse lung migrated at approximately 54,000 daltons (23).

Major cAMP-dependent phosphoproteins in lung cytosol comigrated with several present in cytosol from isolated Type II epithelial cells: $\mathrm{Mr}=260,000,240,000,44,000$, and 22,000 were most prominent in Type II cell cytosol. Phosphorylation of $\mathrm{Mr}$ $=28,000$ (in lung cytosol) and 44,000 (in both lung and Type II cell cytosol) was entirely cAMP-dependent. Their phosphorylation in lung cytosol increased during the perinatal period in association with other aspects of Type II cell differentiation and function; thus endogenous substrates of cAMP-dependent protein kinases are present in both Type II epithelial cells and lung cytosol. cAMP-dependent phosphorylation of $\mathrm{Mr}=44,000$ is highly developmentally regulated in the perinatal period and may play a role in the mediation of the effects of catecholamines or other hormones on Type II epithelial cell function.

Identification and characterization of substrates of cAMPdependent protein kinases are complicated by the complexity of cytosolic proteins from whole lung and by the numerous proteases, protein kinases, and phosphatases which may be present in these crude preparations. In general, evaluation of $\mathrm{x}$-ray films after varying amounts of exposure times was required to demonstrate the various major phosphoproteins described presently. Likewise multiple polyacrylamide gels, $7-13 \%$, were used to better separate specific proteins of interest. More detailed analysis of these proteins will require two-dimensional separation techniques. Addition of protease inhibitors did not alter the major phosphoprotein patterns significantly. Likewise, NaF (10 mM), a phosphatase inhibitor, did not alter phosphorylation although higher concentrations ( $50 \mathrm{mM} \mathrm{NaF}$ ) were inhibitory.

Maturation of pulmonary function has been associated previously with marked changes in $\beta$-adrenergic receptors and catecholamine-sensitive adenylate cyclase activity, which mediate the synthesis of cAMP in lung tissues. CAMP activates protein kinases which catalyze the phosphorylation of regulatory proteins altering their activity and function. The present work demonstrates developmental changes in cAMP-dependent protein kinase activity and marked ontogenic changes in cAMP and $\mathrm{Ca}^{2+}$ dependent phosphorylation of several cytosolic lung proteins. Ontogenic changes in specific protein substrates of protein kinases and their changes in state of phosphorylation in response to cAMP and calcium are likely to mediate developmental changes in pulmonary responses to hormonal stimulation.

\section{REFERENCES AND NOTES}

1. Barrett. C. T.. Sevanian, A., and Kaplan, S. A.: Adenylate cyclase activity in immature rabbit lung. Pediatr. Res., 8: 244 (1974).

2. Boog, G., Brahem, M. B., and Gandar, R.: Beta-mimetic drugs and possible prevention of respiratory distress syndrome. Br. J. Obstet. Gynaecol., 82: 285 (1975)

3. Bourbon, J. and Jost, A.: Control of glycogen metabolism in the developing fetal lung. Pediatr. Res.. 16: 50 (1982).

4. Brandstrup, N. and Kretchmer, N.: The metabolism of glycogen in the lungs of the fetal rabbit. Develop. Biol., 11:202 (1965).

5. Brown. L. A. and Longmore, W. J.: Adrenergic and cholinergic regulation of lung surfactant secretion in the isolated perfused rat lung and in the alveolar type II cell in culture. J. Biol. Chem., 256: 66 (1981). 
6. Burke, B. E. and DeLorenzo, R. J.: $\mathrm{Ca}^{2+}$ - and calmodulin-stimulated endogenous phosphorylation of neurotubulin. Proc. Natl. Acad. Sci. USA, 78: 991 (1981).

7. Cheng, Y. and Prusoff, P.: Relationship between the inhibition constant (Ki) and the concentration of inhibitor which causes 50 percent inhibition (150) of an enzymatic reaction. Biochem. Pharmacol., 22: 3099 (1973).

8. Corbin, J. D., Keely, S. L., and Park, C. R.: The distribution and dissociation of cyclic adenosine $3^{\prime}: 5^{\prime}$-monophosphate-dependent protein kinases in adipose, cardiac and other tissues. J. Biol. Chem., 250: 218 (1975).

9. Dobbs, L. G. and Mason, R. J.: Pulmonary alveolar type Il cells isolated from rats: release of phosphatidylcholine in response to $\beta$-adrenergic stimulation. J. Clin. Invest., 63: 378 (1979).

10. Doskeland, S. O. and Ogreid, D.: Binding proteins for cyclic AMP in mammalian tissues. Int. J. Biochem., 13: 1 (1981).

11. Eipper, B. A.: Rat brain tubulin and protein kinase activity. J. Biol. Chem., 249: 1398 (1974)

12. Eliot, R. J., Klein, A. H., Glatz, T. H., Nathanielsz, P. W., and Fisher, D. A.: Plasma norepinephrine, epinephrine and dopamine concentrations in maternal and fetal sheep during spontaneous parturition and in premature sheep during cortisol-induced parturition. Endocrinology, 108(5): 1678 (1981).

13. Enhorning, G., Chamberlain, D., Conteras, C., Burgoyne, R., and Robertson, B.: Isoxsuprine-induced release of pulmonary surfactant in the rabbit fetus. Am. J. Obstet. Gynecol., I29: 197 (1977).

14. Giannopoulos, G.: Identification and ontogeny of $\beta$-adrenergic receptors in fetal rabbit lung. Biochem. Biophys. Res. Comm., 95: 388 (1980).

15. Gill, G. N. and Walton, G. M.: Assay of cyclic nucleotide-dependent protein kinases. Adv. Cyclic. Nucleotide Res., 10: 93 (1979).

16. Hadjigerogiou, E., Kitsiou, S., Psaroudakis, A., Segos, C., Nicolopoulos, D., and Kaskarelis, D.: Antepartum aminophylline treatment for prevention of the respiratory distress syndrome in premature infants. Am. J. Obstet. Gynecol., 135: 257 (1979).

17. Hallman, M.: Induction of surfactant phosphatidylglycerol in the lung of fetal and newborn rabbits by dibutyryl adenosine $3^{\prime}, 5^{\prime}$ monophosphate. Biochem. Biophys. Res. Comm., 77: 1094 (1977).

18. Kuo, J. F.: Changes in relative levels of guanosine $3^{\prime}: 5^{\prime}$-monophosphatedependent protein kinases in lung, heart and brain of developing guinea pigs. Proc. Nat. Acad. Sci. USA, 72: 2256 (1975).

19. Kuo, J. F.: Reciprocal changes in levels of guanosine $3^{\prime}: 5^{\prime}$-monophosphatedependent protein kinase in developing guinea pig lungs. J. Cyclic Nucleotide Res., 1: 151 (1975).

20. Laemmli, U. K.: Cleavage of structural proteins during the assembly of the head of a bacteriophage T4. Nature (London), 227: 680 (1970).

21. Lawson, E. E., Brown, E. R., Torday, J. S., Madansky, D. L., and Taeusch, H. W., Jr.: The effect of epinephrine on tracheal fluid flow and surfactant efflux in fetal sheep. Am. Rev. Resp. Dis., 118: 1023 (1978).

22. Lowry, O. H., Rosebrough, N. J., Farr, A. L., and Randall, R. J.: Protein measurement with the Folin phenol reagent. J. Biol. Chem., 193: 265 (1951).

23. Malkinson, A. M. and Butley, M. S.: Alterations in cyclic adenosine $3^{\prime}: 5^{\prime}$ monophosphate-dependent protein kinases during normal and neoplastic lung development. Cancer. Res., 41 : 1334 (1981).
24. Malkinson, A. M., Krueger, B. K., Rudolf, S. A., Casnellie, J. E., Haley, B. E., and Greengard, P.: Widespread occurrence of a specific protein in vertebrate tissues and regulation by c-AMP of its endogenous phosphorylation and dephosphorylation. Metabolism, 24: 331 (1975).

25. Maniscalco, W. M., Wilson, C. M., Gross, I., Gobran, L., Rooney, S. A., and Warshaw, J. B.: Development of glycogen and phospholipid metabolism in fetal and newborn rat lung. Biochem. Biophys. Acta., 530:333 (1978).

26. Mettler, N. R., Gray, M. E., Schuffman, S., and LeQuire, V. S.: $\beta$-Adrenergic induced synthesis and secretion of phosphatidylcholine by isolated pulmonary alveolar Type II cells. Lab Invest., 45: 575 (1981).

27. Meyer, W. L., Fischer, E. H. and Krebs, E. G.: Activation of skeletal muscle phosphorylase b kinase by $\mathrm{Ca}^{2+}$. Biochemistry, 3: 1033 (1964).

28. Palmer, G. C.: Characteristics of the hormonal induced cyclic adenosine $3^{\prime}, 5^{\prime}$ monophosphate response in the rat and guinea pig lung in vitro. Biochim Biophys Acta, 252: 561 (1971)

29. Piascik, M., Wisler, P., Johnson, L., and Potter, J. D.: $\mathrm{Ca}^{2+}$-dependent regulation of guinea pig brain adenylate cyclase. J. Biol. Chem., 255:4176 (1980).

30. Powell, W. S. and Solomon, S.: Effects of prostaglandins on the adenylate cyclase activity of lungs from fetal rabbits. Endocrinology, 107: 1469 (1980).

31. Rosen, O. M., Krebs, E. G. (eds): Protein Phosphorylation. In: Cold Spring Harbor Conference on Cell Proliferation, Cold Spring Harbor. Vol 8 New York, NY 1981)

32. Rudolph, S. A. and Krueger, B. K.: Endogenous protein phosphorylation and dephosphorylation. Adv. Cyclic. Nucleotide Res., 10: 107 (1979).

33. Scatchard, G.: The attractions of proteins for small molecules and ions. Ann N. Y. Acad. Sci., 51: 660 (1949).

34. Tordet, C., Bertin, R., Gardey, C., Richard, M. O., Dameron, F., and Marion, L.: Lung catecholamines and cyclic nucleotides during perinatal development in the rat. Possible relationships with biochemical and morphological differentiation. Pediatr. Res., 15: 787 (1981).

35. Walsh, D. A., Ashby, C. D., Gonzalez, C. Calkins, D., Fischer, E. H., and Krebs, E. G.: Purification and characterization of a protein inhibitor of adenosine $3^{\prime}: 5^{\prime}$-monophosphate-dependent protein kinases. J. Biol. Chem., 246: 1977 (1971).

36. Weller, M.: Protein phosphorylation. Appendix 2, pp. 449-450 (Pion Ltd. London, 1979)

37. Whitsett, J. A., Manton, M. A., Darovec-Beckerman, C., and Adams, K.: $\beta$ Adrenergic receptors and catecholamine sensitive adenylate cyclase in the developing rat lung. Life. Sci., 28: 339 (1981).

38. Whitsett, J. A., Manton, M. A., Darovec-Beckerman, C., Adams, K. G., and Moore, J. J.: $\beta$-Adrenergic receptors in the developing rabbit lung. Am. J. Physiol., 240: E351 (1981).

39. Requests for reprints should be addressed to: Dr. J. A. Whitsett, Newborn Division of Pediatrics, Room 6210, Medical Science Building, University of Cincinnati College of Medicine, Cincinnati, Ohio 45267.

40. This research was supported by Research Career Development Award HL 01024 from the National Heart, Lung and Blood Institute, HL 28623, and HD 11725 .

41. Received for publication August 18,1982 .

42. Accepted for publication May 5, 1983. 